\title{
Alçamento Vocálico Sem Motivação Aparente: as vogais médias pretônicas no noroeste do estado de São Paulo
}

\author{
Márcia Cristina do CARMO* \\ Valeska Gracioso CARLOS**
}

* Doutora (2013) e Mestre (2009) em Estudos Linguísticos pela Universidade Estadual Paulista - Campus de São José do Rio Preto (UNESP/IBILCE). Pós-Doutorado (2015) pela University College London (UCL/ Reino Unido). Docente da Universidade Estadual de Ponta Grossa (UEPG). Contato: mccarmo@uepg.br.

** Doutora (2015) e Mestre (2006) em Estudos da Linguagem pela Universidade Estadual de Londrina (UEL). Docente da Universidade Estadual de Ponta Grossa (UEPG). Contato: vgracioso@uol.com.br.

\begin{abstract}
Resumo:
Este artigo investiga o fenômeno fonético-fonológico variável alçamento das vogais médias pretônicas em contexto medial na variedade falada no noroeste do estado de São Paulo, como em $m[i]$ lhor e $c[u]$ lega. Este trabalho discorre especificamente sobre o alçamento sem motivação aparente, ou seja, que não pode ser explicado por harmonização vocálica, engatilhado por uma vogal alta em sílaba subsequente, como em m[i]nino e g[u]rdu ra. Dessa forma, esta pesquisa avança em relação aos estudos de Silveira (2008), Carmo (2009, 2013, 2014, 2018) e Carmo e Tenani (2013) sobre o alçamento das vogais médias pretônicas mediais na mesma variedade. Com o aporte teórico-metodológico da Teoria da Variação e Mudança Linguística (LABOV, 2008), são utilizados, como corpus, 38 inquéritos com amostras de fala espontânea do banco de dados IBORUNA, resultado do projeto ALIP (GONÇALVES, 2007) - (Projeto ALIP - IBILCE/UNESP - FAPESP 03/08058). A análise quantitativa dos dados, por intermédio da utilização do pacote estatístico Goldvarb X, demonstra que o alçamento sem motivação aparente é pouco produtivo na variedade considerada, com índices de $5 \%$ e 10,3\% para /e/ e /o/, respectivamente. De modo geral, verifica-se sua aplicação em paradigmas de determinados itens lexicais, o que corrobora a hipótese da difusão lexical para a explicação do processo (BISOL, 2009).
\end{abstract}

\section{Palavras-chave:}

Variação fonético-fonológica. Vogais médias pretônicas. Alçamento vocálico sem motivação aparente.

Signum: Estudos da Linguagem, Londrina, v. 22, n. 2, p. 114-144, ago. 2019 


\section{Alçamento Vocálico Sem Motivação Aparente: as vogais médias pretônicas no noroeste do estado de São Paulo}

Márcia Cristina do Carmo; Valeska Gracioso Carlos

\section{INTRODUÇÃo}

O presente trabalho analisa o alçamento vocálico sem motivação aparente das vogais médias pretônicas em contexto medial em nomes e verbos na variedade do noroeste do estado de São Paulo, onde está situado o município de São José do Rio Preto. O alçamento vocálico consiste em um fenômeno fonético-fonológico variável a partir do qual as vogais médias-altas /e, o/ são pronunciadas como altas [i, u], respectivamente, como em $s[i] n h o r$ e $\operatorname{alm}[u] c ̧ o u$.

O alçamento vocálico pode ser explicado, em muitos casos, por harmonização, que resulta da influência de uma vogal alta presente na sílaba subsequente à da pretônica-alvo, que atua como um gatilho à aplicação do alçamento, como em s[i]ntido e c[u]stume. Em alguns casos, porém, o alçamento não pode ser explicado por harmonização vocálica, dada a ausência de uma vogal alta na sílaba seguinte à da pretônica-alvo, como em perc[i]besse e $c[u]$ meça. Esses casos têm sido nomeados como alçamento vocálico sem motivação aparente (KLUNCK, 2007; BISOL, 2009; MONARETTO, 2013; SILVA; BIASIBETTI, 2017; BRESCANCINI et al., 2017). Bisol destaca que a harmonização vocálica e o alçamento sem motivação aparente são processos formalmente diferentes, já que o primeiro corresponde a um caso de assimilação de traços, enquanto o segundo consiste em um caso de neutralização.

Esta pesquisa, inédita no que tange à variedade do interior paulista, avança em relação aos estudos de Silveira (2008), Carmo (2009, 2013, 2014, 2018) e Carmo e Tenani (2013), por discorrer especificamente sobre o alçamento sem motivação aparente. Nesse caso, portanto, os dados levantados e analisados são, exclusivamente, de vogais médias pretônicas que não apresentam vogal alta na sílaba imediatamente seguinte, como será exposto na subseção 3.2 deste artigo. Cabe destacar, também, que os estudos já conduzidos que focalizam o alçamento sem motivação aparente descrevem, predominantemente, variedades do Sul do Brasil, especialmente a variedade de Porto Alegre, conforme será explicitado na subseção 2.2.

Como arcabouço teórico-metodológico, segue-se a Teoria da Variação e Mudança Linguística (LABOV, 2008), que concebe a língua como constituída de uma heterogeneidade ordenada, resultante da heterogeneidade da própria comunidade de fala. O corpus desta pesquisa corresponde a 38 entrevistas retiradas do banco de dados 
IBORUNA, resultado do projeto Amostra Linguistica do Interior Paulista - ALIP ${ }^{1}$ (GONÇALVES, 2007). Para a análise quantitativa dos dados, faz-se uso do pacote estatístico Goldvarb X.

Deve-se destacar que a presente investigação faz parte do projeto Descrição Sócio-Histórica das Vogais do Português (do Brasil) (PROBRAVO), liderado pelos professores doutores Seung Hwa-Lee (FALE/UFMG) e Marco Antônio de Oliveira (PUC/MG). Esse projeto analisa, a partir de abordagens multidisciplinares, realizações fonéticas das vogais de diferentes variedades do Português Brasileiro (doravante PB). ${ }^{2}$

O presente artigo encontra-se estruturado da seguinte forma: na primeira seção, a introdução; na segunda, é apresentada a fundamentação teórica que embasa esta pesquisa; logo após, são expostos o material e o método empregados; na sequência, é realizada a análise dos dados; em seguida, as considerações finais e, por fim, as referências.

\section{FundamentaÇão Teórica}

Esta seção discorre sobre o arcabouço teórico concernente à Teoria da Variação e Mudança Linguística (subseção 2.1) e ao processo variável alçamento vocálico sem motivação aparente (subseção 2.2).

\subsection{Teoria da Variação e Mudança Linguística}

As lacunas teóricas referentes à variação e à mudança linguística começaram a ser preenchidas na década de 60 do século XX pela Teoria da Variação e Mudança Linguística, também denominada Sociolinguística Variacionista (LABOV, 2008), que altera o foco do objeto de estudo da Linguística a partir de uma nova concepção de língua, a qual contempla de maneira sistemática a dimensão sócio-histórica do fenômeno linguístico.

O primeiro aporte teórico trazido pelos sociolinguistas é o de que a língua, examinada de modo sincrônico ou diacrônico, deve ser vista como um objeto constituído de uma heterogeneidade ordenada (WEINREICH; LABOV; HERZOG, 2006). Essa nova visão da variação permite entendê-la como uma consequência inevitável da dinâmica interna das línguas e atribui à variação um caráter sistemático e controlado. Nessa perspectiva, a variação já não pode ser concebida como aleatória e irregular, nem a língua como um sistema estático e homogêneo.

Desse modo, o modelo teórico para a variação linguística busca descrever a heterogeneidade ordenada dentro da língua usada por falantes em sua comunidade de

\footnotetext{
${ }^{1}$ Projeto Amostra Linguística do Interior Paulista (ALIP) - FAPESP 03/08058-6, IBILCE/UNESP.

${ }^{2}$ Para mais informações, acessar $<$ http://relin.letras.ufmg.br/probravo/index.php $>$.
} 
fala, também heterogênea. Para Labov (1982, p. 18)3 , “o objeto da descrição linguística é a gramática da comunidade de fala: o sistema de comunicação usado na interação social". Segundo o autor,

A condição normal da comunidade de fala é a da heterogeneidade: podemos esperar encontrar uma larga gama de variantes, estilos, dialetos e linguagens usados por seus membros. Mais ainda, esta heterogeneidade é parte integrante da economia linguística da comunidade, necessárias para satisfazer as demandas linguísticas da vida cotidiana (p. 17).

Ao conceber a língua como heterogênea, consequentemente vislumbra-se um falante com habilidade linguística para lidar com essa heterogeneidade. Dessa maneira, o falante não é visto mais como passivo diante da língua, e passa a agir de forma ativa mais ou menos consciente dentre as várias possibilidades existentes na estrutura linguística. Suas escolhas podem ser determinadas pela situação de comunicação, ou seja, pela sua intenção, pelo seu interlocutor, pelo ambiente no qual se encontra, entre outros fatores. O falante assume um papel de indivíduo histórico e livre, na sua comunidade de fala, criando e recriando a própria língua.

A Sociolinguística mostrou interesse especial pelos estágios que apresentavam relações entre os usos linguísticos e fatores sociais. Desse modo, adota, como objeto de estudo, a língua falada em situação real de uso. Conforme Silva-Corvalán (1989, p. 1),

A sociolinguística é uma disciplina independente, com uma metodologia própria, [...] que estuda a língua em seu contexto social e se preocupa essencialmente em explicar a variabilidade linguística, sua inter-relação com fatores sociais e o papel que essa variabilidade desempenha nos processos de mudança linguística. ${ }^{4}$

Dessa forma, almeja-se estudar a língua falada em situações reais/naturais, razão pela qual o pesquisador deve se aproximar da comunidade de falantes a ser pesquisada e participar diretamente da interação, ou seja, observar de perto o uso da língua nessa comunidade.

Considerando-se que a Sociolinguística Variacionista surge a partir de 1972, com os estudos de Labov (2008), ao observar as mudanças em progresso no inglês da ilha de Martha's Vineyard e da cidade de Nova Iorque, rompe-se o mito de que a mudança linguística poderia ser estudada somente após estar concluída. Com base nesse novo ponto de vista, os estudos da variação possibilitam avançar além da descrição das variantes de uma língua, pois permitem identificar os vários estágios nos processos de mudança,

\footnotetext{
${ }^{3}$ Todas as traduções são nossas.

${ }^{4}$ La sociolingüistica es una disciplina independiente, con una metodología propia, [...] que estudia la lengua en su contexto social y se preocupa esencialmente en explicar la variabilidad lingüistica, de su interrelación con factores sociales y del papel que esta variabilidad desempeña en los procesos de cambio lingüistico.
} 
isto é, se coexistem formas inovadoras implantadas que convivem com as já existentes, ou até mesmo indicar o movimento espacial e social dessa mudança.

A mudança linguística pode ser explicada segundo duas hipóteses: a neogramática e a difusão lexical. A hipótese neogramática, "escola fortemente marcada pelos progressos vividos no final do século XIX pelas ciências naturais" (ILARI, 2018, p. 25), defende que todas as palavras sejam atingidas indistintamente pela mudança linguística, sendo as mudanças lexicalmente abruptas e foneticamente graduais, e que as eventuais exceções à regra sejam explicadas por analogia. Segundo ele, pela forma rígida com a qual o modelo neogramático apresentava a evolução fonética - a qual operaria de maneira cega -, os neogramáticos foram alvo de críticas, principalmente por parte dos dialetólogos. Já a concepção difusionista (WANG, 1969; CHENG; WANG, 1977), por sua vez, defende que cada vocábulo apresenta sua própria história. Nesse caso, as mudanças são implementadas a partir do léxico, sendo lexicalmente graduais e foneticamente abruptas (OLIVEIRA, 1992).

A partir desse arcabouço teórico, o presente estudo analisa o alçamento variável sem motivação aparente das vogais médias pretônicas mediais em nomes e verbos na variedade do noroeste paulista, processo que passa, agora, a ser descrito.

\section{Alçamento Vocálico Sem Motivação Aparente}

Câmara Júnior (2007) afirma haver sete vogais tônicas no PB: /i, e, E, a, O, $\mathrm{O}, \mathrm{u} /{ }^{5}$ Em contexto pretônico, todavia, ocorre o processo de neutralização, desaparecendo a oposição entre as vogais médias-baixas /E, O/ e as médias-altas /e, o/, resultando, portanto, em um quadro composto por cinco vogais: /i, e, a, o, u/.

De acordo com a descrição do autor, baseada na variedade do município do Rio de Janeiro, as vogais médias-altas em contexto pretônico são suscetíveis à harmonização vocálica, pois "as oposições [...] entre /o/ e /u/, de um lado, e, de outro lado, entre /e/ e /i/ ficam prejudicadas pela tendência a harmonizar a altura da vogal pretônica a da vogal tônica" quando esta corresponder a uma vogal alta (p. 44).

O autor destaca também o alçamento das vogais médias pretônicas /e, o/ que não pode ser explicado por harmonização vocálica:

é uma situação semelhante que se repete com /e/e /o/ pretônicos em hiato com um /'a/ tônico, como nos infinitivos voar, passear etc. $\mathrm{O} / \mathrm{i} /$ tende a substituir o /e/, e o /u/ o /o/, dando as pronúncias /vu'r/, /pasi'ar/ etc. Em outros termos, as vogais altas debordam num e noutro caso as vogais médias correspondentes (CÂMARA JÚNIOR, 2007, p. 45).

\footnotetext{
${ }^{5}$ Neste artigo, por motivos de natureza tipográfica, as vogais médias-baixas anterior e posterior são representadas, respectivamente, como /E/ e /O/.
} 
Segundo Bisol (2009), a harmonizaçãa vocálica, como em $c[u] r u j a$ e $m[i] x[i]$ rico, e o alçamento vocálico sem motivação aparente, como em $b[u]$ neca e $c[u] l e ́ g i o$, são processos formalmente diferentes, já que este corresponde a um caso de neutralização, enquanto aquele resulta de assimilação. Ademais, contrapõe os processos pelo fato de a harmonização poder ser explicada pelo modelo neogramático, enquanto a redução da pretônica sem condicionamento fonético corresponde à difusão lexical, "cuja expansão deve ser o produto da ação analógica do falante" (p. 76).

Apesar de os processos de neutralização tenderem a ser categóricos, Bisol (2009) destaca que isso não ocorre na fase inicial do processo, salientando que o alçamento das vogais médias pretônicas, em variedades do Sul do Brasil, corresponde a um processo incipiente e ainda pouco frequente, como demonstra seu estudo anterior sobre o alçamento das vogais médias pretônicas em diferentes variedades do Rio Grande do Sul (BISOL, 1981). De acordo com a autora, no Sul do Brasil, o alçamento sem motivação aparente é mais frequente no que diz respeito à pretônica posterior /o/ e atua esporadicamente em vocábulos isolados, geralmente expandindo-se por palavras aparentadas.

Klunck (2007) analisa o alçamento das vogais médias pretônicas sem motivação aparente especificamente no que tange à variedade de Porto Alegre, utilizando, como corpora, 24 entrevistas do Projeto Variação Linguística na Região Sul do Brasil (VARSUL). Para isso, desconsiderou vocábulos com contexto de harmonização vocálica - isto é, que apresentavam vogal alta em sílaba subsequente -, vogal pretônica /e/ em início de vocábulo seguida de $/ \mathrm{S} /$ e $/ \mathrm{N} /$, prefixo / des-/ inicial e vogais em sequência, formando ditongo ou hiato. Sendo assim, sua análise restringiu-se a palavras como $b /$ o/neca e t/o/mate. A partir de uma análise variacionista, utilizando-se do pacote estatístico VARBRUL, a autora verificou baixos índices de aplicação do alçamento nesse contexto: $4 \%$ para /e/ e 12\% para /o/. Após classificar seus dados como presentes em "grupos de palavras" ou "palavras isoladas", atestou que o alçamento da vogal anterior ocorre esporadicamente, enquanto o da posterior apresenta indício de difusão lexical, pois envolve palavras do mesmo paradigma derivacional, como, por exemplo, $c[u]$ nversa, $c[u]$ nversava, c[u]nversando etc.

Também sobre a variedade de Porto Alegre, Monaretto (2013) analisa o alçamento de vogais médias pretônicas iniciais ${ }^{6}$ e internas sem motivação aparente em um estudo em tempo real de curta duração do tipo painel. ${ }^{7}$ Para tanto, utiliza-se de dados provenientes de entrevistas com 12 indivíduos realizadas em 1970, no âmbito da realização do Projeto

\footnotetext{
${ }^{6}$ Nesse contexto, a autora excetua os vocábulos em que a vogal média pretônica é seguida por sibilante, como em /e/spanta, e por nasal, como em /e/ nxada.

${ }^{7}$ Segundo Paiva e Duarte (2013), o estudo em tempo real de curta duração do tipo painel baseia-se em amostras de fala dos mesmos informantes, separadas por um lapso temporal - no caso da pesquisa de Monaretto (2013), de cerca de 30 anos.
} 
Norma Urbana Culta (NURC), e em 2000, no Projeto VARSUL. A autora analisa os dados em que não há vogal alta nas sílabas seguintes à da pretônica-alvo, como em $p[i] q u e n o$ e $t[u]$ mate. De modo geral, Monaretto observa uma aplicação relativamente baixa do processo, com índices maiores no que diz respeito ao alçamento de /o/ (13,4\% em 1970 e 12,8\% em 2000) do que de /e/ (7,4\% em 1970 e 9\% em 2000) e relativa estabilidade da manutenção do processo, em termos numéricos. A autora destaca que há um crescimento do processo com o passar dos anos dos informantes. Ademais, evidencia a presença de palavras comuns nas duas amostras, bem como a aplicação do processo em vocábulos de paradigmas semelhantes, como em $s[i]$ nhor/s[i]nhora e $c[u]$ mer/c[u]meram/c[u]mendo.

Avança em relação aos estudos anteriores a pesquisa de Silva e Biasibetti (2017), que observa o papel da frequência lexical no alçamento sem motivação aparente das vogais médias pretônicas também na variedade de Porto Alegre, revisitando dados de pesquisas anteriores, como as de Bisol (1981) e Klunck (2007), dentre outras. A partir do arcabouço teórico da Fonologia de Uso (BYBEE, 2001, 2002, 2010) e da Teoria dos Exemplares (JOHNSON, 1997; PIERREHUMBERT, 2001, 2002, 2003), as autoras apontam que não é a frequência per se o fator que determina a propagação do alçamento sem motivação aparente:

o alçamento de vogais médias pretônicas sem motivação aparente se manifesta, majoritariamente, em itens lexicais que possuem relações paradigmáticas mais densas com outros exemplares. Sugere-se que um ambiente fonético específico, embora não seja o responsável por determinar a forma como a variação se propaga, potencialize o alçamento (SILVA; BIASIBETTI, 2017, p. 171).

Nesse sentido, defendem que o processo se propaga gradualmente por entre palavras com base morfológica comum, consistindo, assim, em um processo de natureza morfofonológica. De modo geral, as autoras atestam que, para /e/, o paradigma nominal favorece o alçamento, como em s[i]nhor, s[i]nhora, s[i]nhores e $s[i]$ nhoras. Por outro lado, para /o/, o paradigma verbal exerce maior influência, como em $c[u]$ mescar, c[u]mesco, c[u]mecei e $c[u]$ meçando. Consequentemente, o fato de o alçamento sem motivação aparente ser, geralmente, mais frequente no que se refere à vogal média pretônica posterior é justificado pelas autoras com base nas densas redes dos paradigmas verbais, com suas formas derivadas.

Ainda sobre o alçamento sem motivação aparente na variedade de Porto Alegre, tem-se o estudo de Brescancini et al. (2017), que também analisa sua relação com a frequência do item lexical na língua portuguesa. Para tanto, os autores retomam quatro amostras de fala, englobando 80 entrevistas retiradas do banco de dados VARSUL. Excluíram os contextos de vogal alta na sílaba subsequente, como qu/e/rido e d/o/minada, sílabas iniciais formadas por coda /S/, como /e/stender, ou /N/, como 
/e/ntender, prefixo /des-/, como d/e/sarmar, vogais médias em hiato ou ditongo fonético, como t/e/atro e $c / o / a r$, palavras formadas por justaposição, como t/e/levisão, e palavras funcionais, como $p / o / r q u e$. Segundo os autores, o alçamento sem motivação aparente nas quatro amostras consiste em um processo em variação estável e apresenta índices baixos. Não obstante, os autores destacam a frequência relativamente maior para a vogal pretônica /o/, resultado justificado com base no fato de $[\mathrm{o}]$ e $[\mathrm{u}]$ serem mais próximos do que [e] e [i] na cavidade bucal.

As diferenças do alçamento sem motivação aparente entre /e/ e /o/, segundo Brescancini et al. (2017), não se limitam às distintas taxas de aplicação do processo. Para /e/, a frequência lexical não desempenha papel relevante para o alçamento sem motivação aparente, que ocorre em itens lexicais específicos, como s[i]nhora e p[i]queno(a)(s). Além disso, os autores destacam o alçamento sem motivação aparente de pretônica /e/ precedida por consoante oclusiva alveolar vozeada e seguida por sibilante, como em $d[i]$ sastrada e $d[i]$ spertar, sequência que, segundo os autores, parece sofrer analogia às formas com prefixo /des-/. Já o alçamento de /o/ sem motivação aparente ocorre, sobretudo, em verbos flexionados frequentes na língua, deixando de ser realizado em itens lexicais menos frequentes. Segundo os autores, desempenha papel secundário a informação fonética relativa ao contexto formado por consoante velar precedente em sílaba aberta seguida por consoante nasal, como $c[u] \cdot m e r, c[u] . m e . c e i, c[u] . m$ e.ça $\mathrm{e}$ $c[u] . n$ he.co, ou em sílaba fechada por / N/, como em $c[u]$ n.se.gue, $c[u] n . s e r . t a r, c[u]$ n.ser.va e $c[u]$ n.ver.san.do.

Após a apresentação do processo variável alçamento vocálico sem motivação aparente, bem como de alguns trabalhos que o analisam em outras variedades do $\mathrm{PB}$, a próxima seção descreve a metodologia empregada nesta investigação sobre as vogais médias pretônicas na variedade do noroeste paulista.

\section{Material e Métodos}

Nesta seção, é apresentada uma breve descrição do corpus utilizado nesta pesquisa (subseção 3.1), dos contextos excluídos na presente análise (subseção 3.2) e das variáveis investigadas (subseção 3.3).

\section{Corpus da Pesquisa}

O presente trabalho utiliza, como corpus, inquéritos do banco de dados IBORUNA (GONÇALVES, 2007), resultado do projeto ALIP (FAPESP 03/08058-6), ${ }^{8}$ desenvolvido

\footnotetext{
${ }^{8}$ A primeira autora participou desse projeto como integrante da equipe técnica responsável pela gravação dos inquéritos e pela transcrição ortográfica dos dados, possuindo bolsa de Capacitação Técnica pela FAPESP (Proc. 04/02962-5) de julho de 2004 a fevereiro de 2006.
} 
no IBILCE/UNESP. Esse banco de dados ${ }^{9}$ conta com amostras de fala espontânea de informantes provenientes do noroeste paulista, mais precisamente de São José do Rio Preto e de suas seis cidades circunvizinhas: Bady Bassit, Cedral, Guapiaçu, Ipiguá, Mirassol e Onda Verde.

O banco de dados IBORUNA é formado por dois tipos de amostras: (i) Amostra Censo, composta por 152 amostras de fala controladas sociolinguisticamente; e (ii) Amostra de Interação Dialógica, constituída por amostras coletadas em situações livres de interação social, sem conhecimento prévio dos informantes. No presente estudo, utiliza-se a primeira amostra, por ser aquela que controla os perfis sociais dos informantes entrevistados, possibilitando, assim, o estudo das variáveis extralinguísticas investigadas nesta pesquisa: sexo/gênero, faixa etária e escolaridade (cf. subseção 3.3). Dos 152 inquéritos, este trabalho analisa 38. Esse número provém da combinação de dois sexos/gêneros $\mathrm{x}$ cinco faixas etárias x quatro escolaridades, o que resultaria em 40 inquéritos. Ressalta-se, porém, a inexistência de indivíduos dos sexos/gêneros feminino e masculino com faixa etária de 7 a 15 anos e com Ensino Superior completo ou em andamento, totalizando, portanto, 38 entrevistas analisadas.

Das 38 entrevistas, além dos arquivos sonoros, o banco de dados IBORUNA dispõe de fichas sociais dos informantes, transcrições ortográficas e diários de campo. Em cada inquérito, foram coletados cinco tipos de relatos, a saber: (i) narrativa de experiência pessoal; (ii) narrativa de experiência recontada; (iii) descrição; (iv) procedimento; e (v) opinião. A presente pesquisa utiliza apenas as narrativas de experiência pessoal, a fim de se aproximar o máximo possível do vernáculo do informante, já que, nesse gênero, o falante se envolve emocionalmente, desviando sua atenção para o quê fala, em vez do modo como fala (LABOV, 2008).

Feita a apresentação do corpus, passa-se à descrição dos contextos excluídos da análise.

\section{Contextos Excluídos}

Para uma análise mais sistemática do alçamento sem motivação aparente das vogais médias pretônicas na variedade do noroeste paulista, cinco contextos foram excluídos: (i) pretônicas que apresentavam vogal alta na sílaba imediatamente subsequente, (ii) pretônicas em início de vocábulo; (iii) pretônicas em prefixo; ${ }^{10}$ (iv) pretônicas em ditongo; e (v) pretônicas em biato.

\footnotetext{
${ }^{9}$ Disponível em < iboruna.ibilce.unesp.br >. Acesso em: 12 ago. 2019.

${ }^{10}$ Para a categorização dos prefixos, foi utilizada a seção de etimologia do dicionário Houaiss, sendo mantidos os casos em que determinada forma já havia sido incorporada a outro vocábulo na língua latina.
} 
Em relação à exclusão das pretônicas com vogal alta na silaba subsequente, como em $c[i]$.mi.té.ri.o e $c[u] m$.pu.ta.ção, tal recorte se justifica pelo propósito deste trabalho de analisar o alçamento sem motivação aparente, isto é, que não pode ser explicado por harmonização vocálica. Vale salientar que foram excluídas apenas as ocorrências de pretônicas com vogal alta na sílaba imediatamente seguinte, com base na afirmação de Bisol (1981) de que a harmonização vocálica consiste em um processo que envolve articulações sucessivas e que, portanto, não dá saltos.

No que diz respeito às pretônicas em contexto inicial, como em [i]nfermeira e [u]bedecia, foram excluídas com base na afirmação de Bisol (1981) de que os princípios regentes de seu alçamento não se identificam com aqueles do alçamento da pretônica medial, como confirmado por Carmo (2019), em sua investigação sobre vogais médias pretônicas iniciais na variedade do noroeste paulista.

Já as pretônicas em prefixo, como em $d[i]$ sfazer, em muitos casos, podem ser elididas (BISOL, 1981), como em dsfazer, o que demanda uma investigação à parte. De modo análogo, as pretônicas em ditongo, como em $d[e] i x a r$ e $d[0]$ urado, foram excluídas pelo fato de esse contexto ser passível de outro processo variável, a monotongação, "fenômeno fonológico em que um ditongo passa a ser produzido como uma única vogal" (SILVA, 2011, p. 153) por meio do apagamento do glide, como em $d[e] x a r$ e $d[0]$ rado, sendo deixado, então, para futuras pesquisas.

Por sua vez, as pretônicas em biato, como em chantag [i] ando e j[u]elho, foram excluídas, assim como nos trabalhos de Carmo $(2013,2018)$, para que os resultados quantitativos da análise não fossem enviesados pela alta frequência de alçamento das vogais médias pretônicas presentes nesse contexto (BISOL, 1981).

Excluídas essas ocorrências, foram organizados os grupos de fatores analisados, apresentados na subseção a seguir.

\section{Variáveis Investigadas}

Como variável dependente, tem-se, neste estudo, a aplicação variável do alçamento vocálico sem motivação aparente em vogais pretônicas /e, o/ em meio de vocábulo na variedade do noroeste paulista, como em prof[e]ssora $\sim$ prof[i]ssora e c[o]lega $\sim c[u] l e g a$.

Quanto às variáveis independentes, são consideradas onze, sendo oito linguísticas e três extralinguísticas. A descrição e a justificativa para cada grupo de fatores são elencadas a seguir:

(a) Altura da vogal presente na silaba subsequente: busca-se verificar, por exemplo, se o alçamento ocorre com menor probabilidade quanto mais baixa a altura da vogal da sílaba seguinte. São considerados, então, os fatores: (i) vogal baixa, como em aniv[e]rsário e clo]ração; (ii) vogal média-baixa, como em p[e]rse gue e m[u]leque; e (iii) vogal média-alta, como em m[e]xer e m[o]reno; 
(b) Vogal alta em silaba posterior não imediata: como mencionado na subseção 3.2, foram excluídas as ocorrências de pretônicas seguidas por vogal alta na sílaba imediatamente subsequente, como em v[i].sí.cu.la e pr[u].cu.rar. Todavia, foram mantidas as ocorrências de pretônicas seguidas por vogal alta em sílaba não subsequente, as quais foram controladas por meio dos fatores (i) presença de vogal alta em sílaba seguinte não imediata, como em es.p[e].tá.cu.lo e c[o].nhe.ci; e (ii) ausência de vogal alta em silaba seguinte não imediata, como em $p[e]$.da.lar e f[o]r.ma.do.ra;

(c) Tonicidade da vogal presente na sílaba subsequente: procura-se investigar, por exemplo, se a presença de uma vogal átona na sílaba seguinte à da pretônica-alvo, como em $d[$ e] morou e g[o]staria, exerce maior influência na aplicação do alçamento do que a presença de uma vogal tônica na sílaba seguinte, como em pr[e]ssão e c[o]rtou;

(d) Grau de atonicidade da pretônica-alvo, objetiva-se analisar se o fato de a vogal ser permanentemente átona, como em l[e]vantar - l[e]vanto e pr[o]gramou $\operatorname{pr}[0]$ gramo, favorece o alçamento vocálico, ao passo que a atonicidade variável, como em ch[e]gou - ch[e]go e res[o]lver - res[o]lvo, o desfavorece, como constatado em estudos sobre o alçamento em outras variedades do PB (BISOL, 1981; BORTONI; GOMES; MALVAR, 1992; CASSIQUE et al., 2009, dentre outros);

(e) Estrutura da sílaba: utiliza-se a noção de sílaba proposta por Collischonn (1999) para o PB, com base em Selkirk (1982). ${ }^{11}$ Dessa maneira, são consideradas as seguintes estruturas silábicas: (i) ataque + rima (núcleo), como em fu.t[i].bol; (ii) ataque + rima (núcleo + coda nasal), como em $c[u]$ n.ser.to; (iii) ataque + rima (núcleo + coda sem ser nasal), como em en.g[o]r.dei; (iv) ataque complexo + rima (núcleo), como em pr[i].fe.rí.vel; (v) ataque complexo + rima (núcleo + coda nasal), como em a.pr[e]n.den.do; (vi) ataque complexo + rima (núcleo + coda sem ser nasal), como em em.pr[e]s.ta.da; e (vii) ataque + rima complexa (núcleo + coda complexa), como em c[o]ns.tran.ge.dor,

(f) Ponto de articulação da consoante precedente: verifica-se, aqui, uma possível informação de homorganicidade da pretônica-alvo e do segmento consonantal precedente. Tem-se, como hipótese, o favorecimento da pretônica coronal /e/ por consoante precedente também coronal, como em acon[te]ceu, e da pretônica /o/, dorsal e labial, por consoante dorsal,

\footnotetext{
${ }^{11}$ Conforme defende a autora, a sílaba é constituída, necessariamente, por rima (núcleo) e, geralmente - mas não necessariamente -, por um ataque. Tanto a rima quanto o ataque podem ser ramificados. No caso da rima, quando ramificada, o núcleo é seguido por uma coda.
} 
como em [go]stava, e labial, como de[mo]rou. Embasa essa hipótese o Princípio de Similaridade (HUTCHESON, 1973), que defende que a assimilação, ${ }^{12}$ muitas vezes, ocorre entre segmentos já semelhantes em termos de composição de traços. Além disso, segundo esse princípio, a assimilação, quando estendida, costuma seguir uma espécie de hierarquia de similaridade, partindo, inicialmente, dos segmentos mais próximos;

(g) Ponto de articulação da consoante seguinte: da mesma maneira que a variável independente anterior, espera-se que a presença de uma consoante seguinte coronal, como em $r[e]$ zando, favoreça o alçamento da pretônica /e/, enquanto, para a pretônica /o/, a aplicação do processo seja favorecida por consoantes seguintes dorsal, como em prov [o]cando, e labial, como em c[o]mércio;

(h) Classe gramatical: tem-se, como hipótese, que verbos, como em $s[e]$ paramos e t[o]mando, sejam mais propensos ao alçamento do que nomes, como em empr[e] sários e hem[o]rragia. Isso se justifica pelos sufixos /-i, -ia/ de segunda e de terceira conjugações e pela vogal temática /i/ da terceira. ${ }^{13}$ Como já mencionado, este estudo exclui ocorrências de pretônicas com vogal alta em sílaba imediatamente seguinte, sendo mantidas as pretônicas com vogal alta em sílaba posterior não imediata. Sendo assim, o alçamento em vocábulos como $0 . b[i]$.de.ci.a e $c[u]$ n.se.guir, por exemplo, pode resultar de harmonização, caso a pretônica média-alta na sílaba intermediária seja alçada e passe a funcionar como gatilho para a harmonização da pretônica-alvo;

(i) Sexo/gênero: a partir dos fatores sexo/gênero feminino e sexo/gênero masculino, essa variável é investigada por poder indicar eventual estigma ou prestígio social em relação ao alçamento da vogal média pretônica sem motivação aparente, posto que, como afirma Chambers (2009, p. 115),

em virtualmente todos os estudos sociolinguísticos que incluem uma amostra de homens e mulheres, há evidência para esta conclusão sobre seu comportamento linguístico: as mulheres usam menos variantes estigmatizadas e não padrão do que o fazem os homens do mesmo grupo social nas mesmas circunstâncias. ${ }^{14}$

\footnotetext{
${ }^{12}$ No caso do presente estudo, a pretônica assimila parcialmente a estritura da consoante adjacente (McCARTHY, 2012, em comunicação via e-mail).

${ }^{13} \mathrm{Em}$ relação à harmonização vocálica, Collischonn e Schwindt (2004) destacam ainda o processo categórico harmonia vocálica, por meio do qual a pretônica-alvo corresponde a uma vogal do radical que se apresenta categoricamente alta em outras formas do paradigma, como em s[i]ntir - sinto e $d[u]$ rmindo - durmo.

${ }^{14}$ In virtually all sociolinguistic studies that include a sample of males and females, there is evidence for this conclusion about their linguistic behavior: women use fewer stigmatized and non-standard variants than do men of the same social group in the same circumstances.
} 
(j) Faixa etária: possibilita a investigação do status da mudança linguística em tempo aparente, ${ }^{15}$ a partir da qual se pode observar se o processo variável investigado corresponde a um fenômeno em variação estável ou mudança em progresso. Conforme afirma Chambers (2009), as pessoas da mesma faixa etária têm maiores influências no uso linguístico do que as pessoas mais velhas. Segundo o autor, na adolescência, costuma ocorrer uma maior circulação social e, consequentemente, uma maior exposição a variáveis linguísticas diferentes, podendo levar, por exemplo, à preferência por variantes não favorecidas por adultos. O estudo da mudança em tempo aparente tem, como pressuposto, a hipótese do período crítico de aquisição da linguagem, que aponta que as características linguísticas de jovens adultos tendem a se manter relativamente estáveis ao longo de suas vidas (CHAMBERS, 2009). Compõem essa variável os cinco fatores englobados no banco de dados IBORUNA: (i) de 7 a 15 anos; (ii) de 16 a 25 anos, (iii) de 26 a 35 anos, (iv) de 36 a 55 anos; e (v) acima de 55 anos;

(k) Escolaridade: por meio dessa variável extralinguística, podem ser encontrados eventuais indícios de estigma em relação ao alçamento das vogais pretônicas sem motivação aparente no noroeste paulista, caso, por exemplo, a probabilidade do alçamento seja maior quanto menor for a escolaridade do indivíduo. Como fatores, são investigados os quatro presentes no banco de dados utilizado: (i) primeiro ciclo do Ensino Fundamental; (ii) segundo ciclo do Ensino Fundamental; (iii) Ensino Médio; e (iv) Ensino Superior.

Feita a seleção das variáveis, procedeu-se ao levantamento dos dados, à análise de oitiva ${ }^{16} \mathrm{e}$, em seguida, à quantificação dos resultados, por meio da utilização do programa estatístico Goldvarb X. Os resultados obtidos passam, agora, a ser analisados e discutidos.

\section{Análise E Discussão dos Dados}

Inicialmente, as rodadas de /e/ e de /o/, realizadas separadamente, apresentaram nocautes ${ }^{17}$ quanto à variável estrutura da silaba. Para as duas vogais, pôde-se prosseguir a

\footnotetext{
${ }^{15} \mathrm{O}$ estudo da mudança linguística em tempo aparente diferencia-se do estudo em tempo real, pois, no primeiro, há um estudo linguístico sincrônico dos vernáculos de sujeitos de diferentes faixas etárias, enquanto, no segundo, há observações de textos escritos (tempo real de longa duração) ou dos vernáculos de uma mesma população ou de populações similares em um lapso temporal de uma geração (tempo real de curta duração) (CHAMBERS, 2009; PAIVA; DUARTE, 2013).

${ }^{16} \mathrm{~A}$ análise acústica dos dados mostrou-se inexequível, devido à baixa qualidade das gravações do banco de dados IBORUNA para uma investigação com o uso de recursos específicos, como o software PRAAT (BOERSMA; WEENINK, 2019).

${ }^{17}$ Segundo Guy e Zilles (2007, p. 158), o nocaute diz respeito a um "fator que, num dado momento da análise, corresponde a uma freqüência de $0 \%$ ou de $100 \%$ para um dos valores da variável dependente".
} 
análise estatística apenas a partir do amálgama dos fatores (i) que não apresentavam elemento em coda, como em fu.t[i].bol e pr[i].fe.rível; e (ii) que apresentavam elemento em coda, como em $c[u] n . s e r . t o, e n . g[0] r . d e i$, a.pr[e]n.den.do, em.pr[e]s.ta.da e c[o]ns.tran.ge.dor.

Prosseguindo a análise, como resultado geral, foram identificadas 2.124 vogais pretônicas /e / e 1.619 pretônicas /o/ sem vogal alta na sílaba imediatamente subsequente, como em c[e]rteza e $b[o] n e ́$, contexto para aplicação do alçamento vocálico sem motivação aparente. A Tabela 1, a seguir, apresenta as taxas de alçamento dos dados levantados.

Tabela 1 - Ocorrências gerais de alçamento sem motivação aparente

\begin{tabular}{|c|c|c|}
\hline Variantes & $/ \mathrm{e} /$ & $/ 0 /$ \\
\hline Com alçamento & $5 \%(106 / 2124)$ & $10,3 \%(166 / 1619)$ \\
\hline Sem alçamento & $95 \%(2018 / 2124)$ & $89,7 \%(1453 / 1619)$ \\
\hline Total & $100 \%(2124 / 2124)$ & $100 \%(1619 / 1619)$ \\
\hline
\end{tabular}

Fonte: Elaborada pelas autoras.

Como pode ser observado na Tabela 1 , a frequência de alçamento sem motivação aparente é relativamente baixa, especialmente para a vogal pretônica /e/, como em p[i]queno, que apresenta índice de 5\% de aplicação do fenômeno. Por sua vez, para a pretônica /o/, como em c[u]lega, a taxa de alçamento é um pouco maior, correspondendo a $10,3 \%$ das ocorrências totais. Nota-se, portanto, que o processo é mais produtivo no que tange à vogal média posterior. Esse resultado aproxima a variedade do noroeste paulista às variedades do Sul do Brasil, pois, como mencionado na subseção 2.2 deste artigo, Klunck (2007), Bisol (2009), Monaretto (2013) e Brescancini et al. (2017) também destacam as taxas maiores de alçamento para /o/ nessas variedades, resultado explicado pela maior proximidade entre [o] e [u] do que entre [e] e [i] na cavidade bucal (BRESCANCINI et al., 2017).

A verificação da influência das variáveis independentes investigadas em relação à aplicação do alçamento sem motivação aparente propiciou a realização do quadro a seguir: 
Quadro 1 - Seleção de variáveis pelo programa estatístico

\begin{tabular}{|l|c|c|}
\hline \multicolumn{1}{|c|}{ Variável } & /e/ & /o/ \\
\hline Altura da vogal presente na sílaba subsequente & $2^{\mathrm{a}}$ & $1^{\mathrm{a}}$ \\
\hline Vogal alta em sílaba posterior não imediata & $7^{\mathrm{a}}$ & descartada $\left(3^{\mathrm{a}}\right)$ \\
\hline Tonicidade da vogal presente na sílaba subsequente & $9^{\mathrm{a}}$ & $4^{\mathrm{a}}$ \\
\hline Grau de atonicidade da pretônica-alvo & $1^{\mathrm{a}}$ & descartada $\left(1^{\mathrm{a}}\right)$ \\
\hline Estrutura da sílaba & $5^{\mathrm{a}} / \mathrm{descartada}\left(2^{\mathrm{a}}\right)$ & $2^{\mathrm{a}}$ \\
\hline Ponto de articulação da consoante precedente & $3^{\mathrm{a}}$ & $3^{\mathrm{a}}$ \\
\hline Ponto de articulação da consoante seguinte & $4^{\mathrm{a}}$ & $5^{\mathrm{a}}$ \\
\hline Classe gramatical & $8^{\mathrm{a}}$ & $7^{\mathrm{a}}$ \\
\hline Sexo/gênero & descartada $\left(1^{\mathrm{a}}\right)$ & $6^{\mathrm{a}}$ \\
\hline Faixa etária & $6^{\mathrm{a}}$ & $8^{\mathrm{a}}$ \\
\hline Escolaridade & descartada $\left(3^{\mathrm{a}}\right)$ & descartada $\left(2^{\mathrm{a}}\right)$ \\
\hline
\end{tabular}

Fonte: Elaborado pelas autoras.

Para a pretônica /e/, as variáveis selecionadas foram, em ordem decrescente de relevância: (i) grau de atonicidade da pretônica-alvo; (ii) altura da vogal presente na silaba subsequente; (iii) ponto de articulação da consoante precedente; (iv) ponto de articulação da consoante seguinte; (v) estrutura da sílaba; (vi) faixa etária; (vii) vogal alta em sílaba posterior não imediata; (viii) classe gramatical; e (ix) tonicidade da vogal presente na sílaba subsequente. Foram descartadas pelo programa estatístico as variáveis sexo/gênero, estrutura da sílaba e escolaridade. Cabe ressaltar que a variável estrutura da silaba, embora selecionada como a quinta mais relevante, foi a segunda descartada pelo programa estatístico, apresentando, portanto, comportamento indefinido.

Por sua vez, para a vogal pretônica /o/, foram selecionadas as variáveis: (i) altura da vogal presente na silaba subsequente; (ii) estrutura da silaba; (iii) ponto de articulaşão da consoante precedente; (iv) tonicidade da vogal presente na silaba subsequente; (v) ponto de articulação da consoante seguinte; (vi) sexo/gênero; (vii) classe gramatical; e (viii) faixa etária. Foram apontadas como não relevantes as variáveis grau de atonicidade da pretônica-alvo, escolaridade e vogal alta em sílaba posterior não imediata.

A partir da observação do Quadro 1, destaca-se o comportamento diferenciado do alçamento sem motivação aparente para as vogais /e/ e /o/, tendo em vista as diferentes seleções de variáveis. Por exemplo, a variável selecionada como mais importante para o alçamento sem motivação aparente de /e/, o grau de atonicidade da pretônica-alvo, foi descartada para $/ o /$. 
De modo geral, os comportamentos de /e/ e de /o/ em relação ao alçamento sem motivação aparente se assemelham por serem resultado, primordialmente, da atuação de fatores linguísticos. Atesta-se a baixa influência das variáveis extralinguísticas, com comportamentos pouco expressivos para o alçamento das vogais médias pretônicas. Como já mencionado, a variável sexo/gênero foi descartada para /e/ e, para /o/, foi selecionada como a sexta mais relevante. A faixa etária foi selecionada como sexta e oitava variável mais relevante para o alçamento de /e/ e /o/, respectivamente. Finalmente, a variável escolaridade foi descartada tanto para o alçamento de /e/ quanto de /o/, resultado que indica que o alçamento sem motivação aparente dessas vogais na variedade analisada não é influenciado pelo menor ou maior grau de instrução formal do falante. A princípio, há indícios de não se tratar de um processo estigmatizado socialmente, o que pode ser confirmado, por exemplo, pela condução de testes de reação subjetiva, o que é deixado para futuras pesquisas.

Os resultados de cada variável passam, agora, a ser descritos mais detalhadamente.

\section{Variáveis Linguísticas}

Como exposto anteriormente, a variável grau de atonicidade da pretônica-alvo, descartada em relação ao alçamento de /o/, foi apontada como a mais relevante para o alçamento de /e/. Seus resultados são verificados na Tabela 2:

Tabela 2 - Ocorrências de alçamento em relação à variável gran de atonicidade da pretônica-alvo

\begin{tabular}{lcc}
\hline & \multicolumn{2}{c}{$/ \mathrm{e} /$} \\
Fatores & Frequência & PR \\
\hline Permanente & $9,9 \%(94 / 954)$ & 0.893 \\
Variável & $1 \%(12 / 1170)$ & 0.151 \\
\hline Total & $\mathbf{5 \% ( 1 0 6 / 2 1 2 4 )}$ & \\
\hline
\end{tabular}

Input: 0.006

Signif.: 0.006

Fonte: Elaborada pelas autoras.

Como pode ser visto na Tabela 2, a atonicidade permanente, como em p[i]queno, favorece o alçamento, com peso relativo (doravante, PR) 0.893. Por outro lado, a atonicidade variável, como em esqu[e]cer, desfavorece a aplicação do processo, com PR 0.151. Esse resultado confirma, para /e/, a hipótese inicial (cf. subseção 3.3) de o alçamento ser favorecido pela natureza permanentemente átona da vogal, como observado em outras 
variedades do PB (BISOL, 1981; BORTONI; GOMES; MALVAR, 1992; CASSIQUE et al., 2009, dentre outros). Para /o/, o descarte da variável evidencia sua não atuação para o alçamento sem motivação aparente, o que refuta a hipótese inicial.

Verificam-se, agora, os resultados referentes à altura da vogal presente na sílaba subsequente, variável selecionada como a segunda mais relevante para o alçamento de /e/ e a primeira para /o/ (cf. Quadro 1).

Tabela 3 - Ocorrências de alçamento em relação à variável altura da vogal presente na silaba subsequente

\begin{tabular}{|c|c|c|c|c|}
\hline \multirow[b]{2}{*}{ Fatores } & \multicolumn{2}{|c|}{$/ \mathrm{e} /$} & \multicolumn{2}{|l|}{$/ \mathrm{o} /$} \\
\hline & Frequência & PR & Frequência & PR \\
\hline Média-alta & $6,9 \%(89 / 1285)$ & 0.807 & $13,4 \%(117 / 874)$ & 0.666 \\
\hline Média-baixa & $13,9 \%(16 / 115)$ & 0.790 & $32,8 \%(42 / 128)$ & 0.922 \\
\hline Baixa & $0,1 \%(1 / 724)$ & 0.060 & $1,1 \%(7 / 617)$ & 0.185 \\
\hline Total & $5 \%(106 / 2124)$ & & $10,3 \%(166 / 1619)$ & \\
\hline & $\begin{array}{l}\text { Input: } 0.006 \\
\text { Signif.: } 0.006\end{array}$ & & $\begin{array}{l}\text { Input: } 0.025 \\
\text { Signif.: } 0.047\end{array}$ & \\
\hline
\end{tabular}

Fonte: Elaborada pelas autoras.

Por meio da Tabela 3, observa-se que a presença de uma vogal média, seja ela média-alta (PRs 0.807 e 0.666 para /e/ e /o/, respectivamente), como em prof[i] ssor e cot[u]velo, ou média-baixa (PRs 0.790 e 0.922 ), como em $m[i] l$ thor e $c[u]$ nhece, favorece a aplicação do processo. Por outro lado, a presença de uma vogal baixa em sílaba subsequente à pretônica-alvo, como em $p[e]$ sada e $c[0]$ rtar, desfavorece a aplicação do alçamento, com PRs 0.060 para /e/ e 0.185 para /o/.

Esses resultados parecem confirmar, a princípio, a hipótese de que quanto mais baixa a vogal, menor o índice de alçamento, com exceção das vogais médias-baixas, que apresentam índices altos de aplicação do processo. Seus resultados podem ser relativizados quando observados os vocábulos alçados, posto que as 16 vogais pretônicas /e/ alçadas seguidas por vogal média baixa ocorrem em apenas três itens lexicais: fut [i]bol ( 2 ocorrências), $m$ [i] lhor (2 ocorrências) e $s[i]$ nhora (12 ocorrências), resultado que corrobora a hipótese difusionista. Já as 42 ocorrências de alçamento da pretônica /o/ seguida por vogal média-baixa encontram-se nos vocábulos: $b[u] n e ́$ (1 ocorrência), $c[u] \operatorname{leg} a$ (4 ocorrências), $J[u] s e ́$ (4 ocorrências), $m[u] l$ leque (28 ocorrências), $m[u]$ lequinho (3 ocorrências), c cu]meşa (1 ocorrência) e $c[u]$ nhece (1 ocorrência), cuja aplicação parece ser mais bem explicada pela influência do ponto de articulação da consoante precedente à pretônica-alvo. 
$\mathrm{Na}$ Tabela 4, são expostas as ocorrências referentes à variável ponto de articulação da consoante precedente, selecionada como terceira mais relevante para o alçamento de /e/ e de $/ \mathrm{o} /$.

Tabela 4 - Ocorrências de alçamento em relação à variável ponto de articulação da consoante precedente

\begin{tabular}{lcccc}
\hline & \multicolumn{2}{c}{$/ \mathrm{e} /$} & \multicolumn{2}{c}{$/ \mathbf{o}$} \\
Fatores & Frequência & PR & Frequência & PR \\
\hline Coronal & $6,3 \%(67 / 1060)$ & 0.622 & $2,4 \%(10 / 425)$ & 0.201 \\
Dorsal & $0,5 \%(1 / 185)$ & 0.049 & $13,2 \%(106 / 804)$ & 0.495 \\
Labial & $4,3 \%(38 / 879)$ & 0.506 & $12,8 \%(50 / 390)$ & 0.824 \\
\hline Total & $\mathbf{5 \% ( 1 0 6 / 2 1 2 4 )}$ & \multicolumn{3}{c}{$\mathbf{1 0 , 3 \% ( \mathbf { 1 6 6 / 1 6 1 9 ) }}$} \\
\hline & Input: 0.006 & Input: 0.025 \\
& Signif.: 0.006 & Signif.: 0.047 &
\end{tabular}

Fonte: Elaborada pelas autoras.

Pela Tabela 4, pode-se observar a presença de consoante coronal antecedente à pretônica, como em [se]nhora e [lo]cais, favorece o alçamento vocálico de /e/ (PR 0.622), e desfavorece o alçamento de /o/ (PR 0.201). Por sua vez, a presença de uma consoante labial em contexto precedente, como em atra[ve]ssar e [pu]lenta, mostra-se neutra em relação ao alçamento de /e/ (PR 0.506), e favorece o alçamento de /o/ (PR 0.824). Por fim, consoantes dorsais, como em es[ke]cer e ver[go]nhoso, desfavorecem o alçamento de /e/ (PR 0.049) e são neutras em relação ao alçamento de /o/ (PR 0.495).

Os resultados que indicam o favorecimento do alçamento sem motivação aparente da pretônica /e/ por consoante precedente coronal e da pretônica /o/ por consoante labial corroboram a hipótese inicial (cf. seção 3.3) baseada no Princípio de Similaridade (HUTCHESON, 1973), tendo em vista a homorganicidade de traços presente entre a pretônica e a consoante antecedente.

No que diz respeito ao contexto subsequente à pretônica-alvo, foram obtidos os seguintes resultados: 
Tabela 5 - Ocorrências de alçamento em relação à variável ponto de articulação da consoante seguinte

\begin{tabular}{|c|c|c|c|c|}
\hline \multirow[b]{2}{*}{ Fatores } & \multicolumn{2}{|c|}{$/ \mathrm{e} /$} & \multicolumn{2}{|c|}{$/ 0 /$} \\
\hline & Frequência & PR & Frequência & PR \\
\hline Coronal & $5,5 \%(75 / 1365)$ & 0.473 & $8,1 \%(81 / 994)$ & 0.469 \\
\hline Dorsal & $6,1 \%(27 / 440)$ & 0.785 & $1,9 \%(3 / 157)$ & 0.178 \\
\hline Labial & $1,3 \%(4 / 319)$ & 0.210 & $17,5 \%(82 / 468)$ & 0.684 \\
\hline Total & $5 \%(106 / 2124)$ & & $10,3 \% 166 / 1619)$ & \\
\hline & $\begin{array}{l}\text { Input: } 0.006 \\
\text { Signif.: } 0.006\end{array}$ & & $\begin{array}{l}\text { Input: } 0.025 \\
\text { Signif.: } 0.047\end{array}$ & \\
\hline
\end{tabular}

Fonte: Elaborada pelas autoras.

Os resultados relativos ao ponto de articulação da consoante seguinte à pretônica-alvo, variável selecionada como a quarta e a quinta mais relevantes para o alçamento de, respectivamente, /e/ e /o/, mostram que para /e/, a consoante dorsal, como em ap [i]guei, favorece o alçamento (PR 0.785). Deve-se destacar que, além do exemplo já mencionado, as outras 26 ocorrências de alçamento neste contexto correspondem unicamente a vocábulos do paradigma de $p[i] q u e n o$. Já para a pretônica /o/, como col[o]cavam, a consoante dorsal em posição seguinte mostra-se desfavorecedora (PR 0.178).

A consoante labial, como em l[e]vantava e $c[u]$ meşamos, desfavorece o alçamento de /e/ (PR 0.210) e favorece a aplicação do processo para /o/ (PR 0.684), o que pode ser explicado pela homorganicidade do traço de labialidade entre a consoante e a vogal média posterior, o que vai ao encontro do Princípio de Similaridade de Hutcheson (1973). Conforme afirma Bisol (1981), o favorecimento do alçamento pela consoante labial é favorecido pelo fato de $[\mathrm{u}]$ ser mais labializado do que [o].

Por sua vez, a consoante coronal seguinte, como em r[e]solven e dec[o]rar, mostra-se relativamente neutra para a aplicação do alçamento tanto de /e/ (PR 0.473) quanto de /o/ (PR 0.469).

Apesar de seu comportamento indefinido em relação à pretônica-alvo /e/, os resultados referentes à estrutura da silaba, variável selecionada como quinta mais relevante para /e/ ${ }^{18}$ e segunda para /o/, são expostos na Tabela 6 para ambas as vogais pretônicas.

\footnotetext{
${ }^{18}$ E também descartada para a vogal média pretônica anterior (cf. Quadro 1), o que evidencia seu comportamento indefinido para essa vogal.
} 
Tabela 6 - Ocorrências de alçamento em relação à variável estrutura da sílaba

\begin{tabular}{|c|c|c|c|c|}
\hline \multirow[b]{2}{*}{ Fatores } & \multicolumn{2}{|l|}{$/ \mathrm{e} /$} & \multicolumn{2}{|l|}{ /o/ } \\
\hline & Frequência & PR & Frequência & PR \\
\hline Sem elemento em coda & $\begin{array}{c}4,9 \% \\
(79 / 1626)\end{array}$ & 0.470 & $\begin{array}{c}15,1 \% \\
(151 / 1000)\end{array}$ & 0.684 \\
\hline Com elemento em coda & $\begin{array}{c}5,4 \% \\
(27 / 498)\end{array}$ & 0.596 & $\begin{array}{c}2,4 \% \\
(15 / 619)\end{array}$ & 0.223 \\
\hline Total & $\begin{array}{c}5 \% \\
(106 / 2124)\end{array}$ & & $\begin{array}{c}10,3 \% \\
(166 / 1619)\end{array}$ & \\
\hline & $\begin{array}{l}\text { Input: } 0.006 \\
\text { Signif.: } 0.006\end{array}$ & & $\begin{array}{l}\text { Input: } 0.025 \\
\text { Signif.: } 0.047\end{array}$ & \\
\hline
\end{tabular}

Fonte: Elaborada pelas autoras.

No que diz respeito à pretônica /e/, a ausência de elemento em coda, como em $\operatorname{pr}[$ e].pa.ro, é relativamente neutra em relação ao alçamento (PR 0.470). Já a presença de segmento em coda, como em $d[i]$ s.co.bri, é apontada como favorecedora do alçamento (PR 0.596). Cabe ressaltar, todavia, que as 27 ocorrências de alçamento da pretônica /e/ em sílaba travada correspondem à sequência / des-/, a saber: $d[i]$ spedida, $d[i]$ spedido, $d[i]$ spesa(s) (3 ocorrências), $d[i]$ scobri (7 ocorrências), $d[i]$ scobrimos, $d[i]$ scobrindo, $d[i]$ scobrir (3 ocorrências), $d[i]$ scobriram, $d[i]$ scobriu, $d[i]$ sconfiar, $d[i]$ scontar (2 ocorrências), $d[i]$ screver, $d[i]$ smaiei e $d[i]$ spertou (3 ocorrências). Como citado na subseção 2.2 deste trabalho, o favorecimento do alçamento da pretônica /e/ pelo contexto de consoante oclusiva alveolar vozeada precedente e consoante sibilante seguinte é destacado por Brescancini et al. (2017), que afirmam que tal sequência parece sofrer analogia em relação ao prefixo /des-/.

Resultado diferente é encontrado para /o/, em que a ausência de elemento em coda, como em $b[u] . n e ́$, favorece o alçamento (PR 0.684), enquanto a presença de elemento em coda, como em g[o]s.ta.va, desfavorece a aplicação do fenômeno (PR 0.223).

No que concerne à variável vogal alta em sílaba posterior não imediata, selecionada como relevante apenas para o alçamento de /e/ (sétima posição), os resultados são expostos na tabela a seguir. 
Tabela 7 - Ocorrências de alçamento em relação à variável vogal alta em silaba posterior não imediata

\begin{tabular}{lcc}
\hline & \multicolumn{2}{c}{$/ \mathrm{e} /$} \\
Fatores & Frequência & PR \\
\hline Presença & $20,3 \%(27 / 133)$ & 0.814 \\
Ausência & $4 \%(79 / 1991)$ & 0.475 \\
\hline Total & $\mathbf{5 \% ( 1 0 6 / 2 1 2 4 )}$ & \\
\hline
\end{tabular}

Input: 0.006

Signif.: 0.006

Fonte: Elaborada pelas autoras.

Como pode ser observado, a ausência de vogal alta em sílaba seguinte, como em es.cr[e].ver, mostra certa neutralidade em relação ao alçamento (PR 0.475). Já a presença de uma vogal alta em sílaba seguinte não imediata, como em $d[i]$ s.co.bri, favorece o alçamento de /e/ (PR 0.814).

As 27 ocorrências de alçamento sem motivação aparente de /e/ com vogal alta presente em sílaba posterior não imediata correspondem a: $d[i]$ spedida, $d[i]$ spedido, p[i]quenininho(a) (6 ocorrências), pr[i]ferivel, trav[i]sseirinho, d[i]scobri (7 ocorrências), $d[i]$ scobrimos, $d[i]$ scobrindo, $d[i]$ scobrir (3 ocorrências), d[i] scobriram, $d[i]$ scobriu, $d[i]$ sconfiar e ob[i]dęcia (2 ocorrências). Dessas 27 ocorrências, 17 apresentam a pretônica /e/ em /des-/, sequência já destacada anteriormente. Das outras 10 ocorrências, 9 apresentam alçamento da vogal média presente na sílaba intermediária, ${ }^{19}$ que passa a engatilhar o alçamento por meio de harmonização vocálica. Exceção corresponde ao vocábulo trav[i] sseirinho, o que pode ser explicado pelo fato de o sufixo /-inho/ inibir a aplicação da harmonização vocálica, por atuar no âmbito de fronteira de vocábulo (BISOL, 1981). Nesse caso, atua em prol do alçamento a atonicidade permanente da vogal pretônica (trav [i]sseirinho - trav[i]sseiro), contexto que favorece o alçamento sem motivação aparente de /e/ (cf. Tabela 2).

A Tabela 8, apresentada a seguir, expõe os resultados relativos ao grupo de fatores classe gramatical, selecionado como o oitavo mais relevante para /e/ e o sétimo para /o/.

${ }^{19}$ A saber: $p[i] q u[i]$ ninho(a) (6 ocorrências), pr[i]f[i]rivel e ob[i]d[i]cia (2 ocorrências). 
Tabela 8 - Ocorrências de alçamento em relação à variável classe gramatical

\begin{tabular}{|c|c|c|c|c|}
\hline \multirow[b]{2}{*}{ Fatores } & \multicolumn{2}{|c|}{$/ \mathrm{e} /$} & \multicolumn{2}{|c|}{ /o/ } \\
\hline & Frequência & PR & Frequência & PR \\
\hline Nome & $7,6 \%(70 / 923)$ & 0.351 & $10,4 \%(57 / 548)$ & 0.410 \\
\hline Verbo & $3 \%(36 / 1201)$ & 0.616 & $10,2 \%(109 / 1071)$ & 0.546 \\
\hline \multirow[t]{3}{*}{ Total } & $5 \%(106 / 2124)$ & & $10,3 \%(166 / 1619)$ & \\
\hline & Input: 0.006 & & Input: 0.025 & \\
\hline & Signif.: 0.006 & & Signif.: 0.047 & \\
\hline
\end{tabular}

Fonte: Elaborada pelas autoras.

Como pode ser observado na Tabela 8 , o fato de a pretônica ocorrer em um verbo, como em ob[i]decia e $c[u] m e r$, favorece o alçamento tanto de /e/ (PR 0.616) quanto de /o/ (PR 0.546). Já a presença da pretônica em nome, como em s[e]mana e c[o]rrentęa, desfavorece o alçamento para ambas as pretônicas (PRs 0.351 para /e/ e 0.410 para /o/). Esse resultado, a princípio, confirmaria a hipótese inicial desta pesquisa (cf. subseção 3.3) de que verbos estariam mais propensos à aplicação do processo, pela presença de sufixos /-i, -ia/ de segunda e de terceira conjugações e pela vogal temática /i/ da terceira.

Não obstante, quando verificados os dados alçados, das 36 ocorrências de /e/ alçadas, 22 estão presentes na sequência já citada /des-/, presentes nos paradigmas verbais de $d[i]$ scobrir, $d[i]$ sconfiar, $d[i]$ scontar, $d[i]$ screver, $d[i]$ smaiar e $d[i]$ spertar. Em relação a /o/, das 109 ocorrências, 90 correspondem aos paradigmas verbais de $c[u] m$ eçar, $c[u] m$ er, $c[u] m$ entar, $c[u] m$ preender, $c[u] n$ hecer, $c[u] n$ sertar e $c[u] n$ versar. Essa averiguação das ocorrências indicia, para a variedade do noroeste paulista, a influência do contexto de pretônica /o/ precedida por consoante velar/dorsal e seguida por consoante nasal na sílaba seguinte, ou, ainda, por $/ \mathrm{N} /$ em coda, contexto destacado por Brescancini $e t$ al. (2017) para a variedade de Porto Alegre.

Finalmente, são exibidos os resultados referentes à tonicidade da vogal presente na silaba subsequente, variável selecionada como nona e quarta mais relevante para /e/ e /o/, respectivamente. 
Tabela 9 - Ocorrências de alçamento em relação à variável tonicidade da vogal presente na sílaba subsequente

\begin{tabular}{|c|c|c|c|c|}
\hline & \multicolumn{2}{|c|}{$/ \mathrm{e} /$} & \multicolumn{2}{|c|}{ /o/ } \\
\hline Fatores & Frequência & PR & Frequência & PR \\
\hline Tônica & $4 \%(69 / 1735)$ & 0.552 & $6,5 \%(67 / 1038)$ & 0.379 \\
\hline Átona & $9,5 \%(37 / 389)$ & 0.282 & $17 \%(99 / 581)$ & 0.707 \\
\hline Total & $5 \%(106 / 2124)$ & & $10,3 \%(166 / 1619)$ & \\
\hline & Input: 0.006 & & Input: 0.025 & \\
\hline & Signif.: 0.006 & & Signif.: 0.047 & \\
\hline
\end{tabular}

Fonte: Elaborada pelas autoras.

São observados, na Tabela 9, resultados diferentes para /e/ e /o/. O alçamento de /e/ é levemente favorecido pela presença de uma vogal tônica na sílaba seguinte, como em fut [i]bol (PR 0.552), e desfavorecido pela presença de uma vogal átona (PR 0.282), como em irr[e]sponsabilidade. Por sua vez, o alçamento de /o/ é desfavorecido pela presença de uma vogal tônica (PR 0.379), como em jap[o]nês, e favorecido pela presença de uma vogal átona (PR 0.707), como em s[u]ssegado.

Apesar da seleção da variável tonicidade da vogal presente na silaba subsequente para o alçamento sem motivação aparente das pretônicas /e/ e /o/, como já apontado em relação a variáveis anteriores, a aplicação do processo parece estar atrelada a paradigmas específicos de determinados itens lexicais, especialmente no que diz respeito à vogal pretônica /o/ e os paradigmas verbais de alm[u]çar (7 ocorrências), c[u]meçar (61 ocorrências), c[u]mer (4 ocorrências), c[u]nhecer (15 ocorrências), c[u]nversar (7 ocorrências) e $p[u] \operatorname{der}$ (4 ocorrências). Para /e/, destacam-se os grupos de palavras: $d[i] \operatorname{spesa(s)}$ (3 ocorrências), p[i]queno(a)(s) e p[i]quenininho(a) (26 ocorrências), prof[i]ssor(a) (6 ocorrências), s[i]nhor(a) (23 ocorrências), t[i]soura e t[i]soureiro (4 ocorrências), bem como o paradigma verbal de $d[i]$ scobrir (14 ocorrências). Sendo assim, os resultados referentes ao alçamento sem motivação aparente no noroeste paulista corroboram a hipótese difusionista para a explicação do processo, corroborando, também, estudos anteriores sobre variedades sulistas do PB (cf. subseção 2.2).

Em suma, no que concerne às variáveis linguísticas, os resultados quantitativos apontam, de modo geral, o favorecimento do alçamento de /e/ pelos contextos em que essa vogal: (i) tem natureza permanentemente átona; (ii) é precedida por consoante coronal; e (iii) é seguida por vogal média-alta na sílaba seguinte. Por sua vez, para /o/, mostram-se favorecedores do alçamento os contextos em que a pretônica: (i) é precedida e/ou seguida por consoante labial; (ii) apresenta-se em sílaba aberta; e (iii) é seguida por vogal média-alta na sílaba subsequente. Vocábulos que atendem a esses critérios são, respectivamente, $d[i]$ s.co.brir e $c[u] . m e . c a r$, destacados no parágrafo anterior pela grande frequência de alçamento em seus paradigmas verbais. 
São analisados, na próxima subseção, os dados concernentes às variáveis extralinguísticas relevantes ao alçamento sem motivação aparente no noroeste paulista: sexo/gênero e faixa etária.

\section{Variáveis Extralinguísticas}

Como apresentado no Quadro 1, a variável sexo/gênero foi selecionada como relevante apenas no que tange ao alçamento da vogal pretônica /o/, ocupando a sexta posição.

Tabela 10 - Ocorrências de alçamento sem motivação aparente em relação à variável sexo/gênero

\begin{tabular}{lcc}
\hline & \multicolumn{2}{c}{$/ \mathbf{o} /$} \\
Fatores & Frequência & PR \\
\hline Feminino & $7,3 \%(59 / 807)$ & 0.379 \\
Masculino & $13,2 \%(107 / 812)$ & 0.620 \\
\hline Total & $\mathbf{1 0 , 3 \% ( 1 6 6 / 1 6 1 9 )}$ \\
\hline & Input: 0.025 & \\
& Signif.: 0.047 &
\end{tabular}

Fonte: Elaborada pelas autoras.

A Tabela 10 demonstra que a probabilidade de ocorrência de alçamento de /o/ na fala do sexo/gênero feminino é de 0.379 , ao passo que, para o sexo/gênero masculino, é de 0.620. Consequentemente, pode-se afirmar que o sexo/gênero masculino do informante favorece a aplicação do processo, enquanto o sexo/gênero feminino o desfavorece.

Como já mencionado na subseção 3.3 deste trabalho, as mulheres usam variantes estigmatizadas e não padrão com frequência menor do que os homens de seu mesmo grupo social (CHAMBERS, 2009). Apesar da exclusão da variável escolaridade - a qual poderia fornecer maiores indícios de se tratar de um processo estigmatizado socialmente -, a partir dos resultados obtidos nesta pesquisa para a variável sexo/gênero pode-se afirmar que o alçamento sem motivação aparente da vogal pretônica /o/ parece ser, a princípio, estigmatizado socialmente, visto que as mulheres tendem a evitá-lo, enquanto os homens o aplicam com maior probabilidade, como ilustrado no Gráfico 1. Já para /e/, a não seleção do sexo/gênero corrobora a informação de que não se trata de um processo estigmatizado socialmente, no que tange ao alçamento dessa vogal. Esses resultados iniciais podem ser confirmados ou refutados por meio da realização de testes de reação subjetiva, deixados para futuros estudos. 


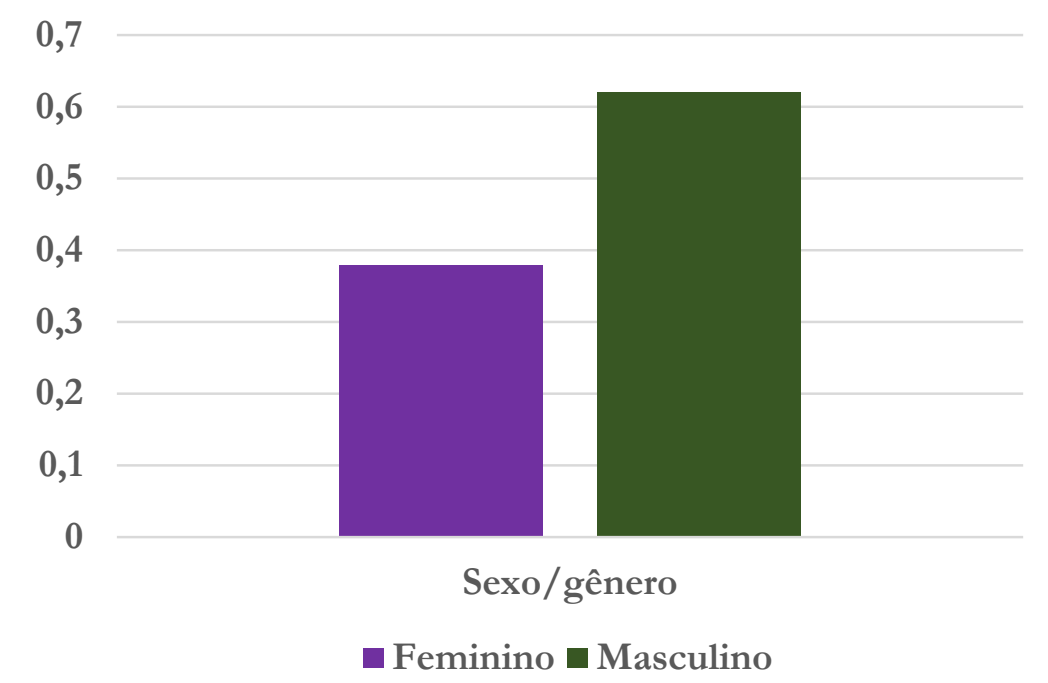

Fonte: Elaborado pelas autoras.

Gráfico 1 - Probabilidades de aplicação do alçamento sem motivação aparente de /o/ em relação ao sexo/gênero

A faixa etária, como observado no Quadro 1, foi selecionada como, respectivamente, sexta e oitava variável mais relevante para a aplicação do alçamento de /e/ e de /o/. Verificam-se, para essas vogais, comportamentos bastante diferenciados, como mostra a Tabela 11.

Tabela 11 - Ocorrências de alçamento sem motivação aparente em relação à variável faixa etária

\begin{tabular}{lcccc}
\hline & \multicolumn{2}{c}{$/ \mathrm{e} /$} & \multicolumn{2}{c}{$/ \mathbf{o} /$} \\
Fatores & Frequência & PR & Frequência & PR \\
\hline $\mathbf{7}$ a $\mathbf{1 5}$ anos & $2,6 \%(10 / 388)$ & 0.324 & $13,1 \%(46 / 350)$ & 0.542 \\
$\mathbf{1 6}$ a $\mathbf{2 5}$ anos & $3,8 \%(13 / 338)$ & 0.475 & $11,6 \%(37 / 320)$ & 0.532 \\
$\mathbf{2 6}$ a $\mathbf{3 5}$ anos & $4,5 \%(16 / 355)$ & 0.475 & $11,1 \%(27 / 244)$ & 0.623 \\
$\mathbf{3 6}$ a $\mathbf{5 5}$ anos & $7,5 \%(45 / 602)$ & 0.650 & $8,4 \%(31 / 371)$ & 0.456 \\
Acima de $\mathbf{5 5}$ & $5 \%(22 / 441)$ & 0.491 & $7,5 \%(25 / 334)$ & 0.385 \\
anos & & & & \\
\hline Total & $\mathbf{5 \% ( 1 0 6 / 2 1 2 4 )}$ & $\mathbf{1 0 , 3 \% ( 1 6 6 / 1 6 1 9 )}$ \\
\hline & Input: 0.006 & Input: 0.025 \\
& Signif.: 0.006 & Signif.: 0.047
\end{tabular}

Fonte: Elaborada pelas autoras. 
No que tange à vogal pretônica anterior, a faixa etária que mais aplica o alçamento sem motivação aparente é a de informantes de 36 a 55 anos, com 7,5\% de aplicação e PR 0.650. Em seguida, a faixa etária mais avançada, de mais de 55 anos, apresenta PR próximo ao ponto neutro 0.491 , bem como adolescentes e jovens - de 16 a 25 anos e de 26 a 35 anos -, com PR 0.475, para ambas. Por fim, os mais jovens, de 7 a 15 anos, parecem reter a aplicação do processo, com PR 0.324. Poder-se-ia constatar que o alçamento sem motivação aparente da vogal pretônica /e/ se encontra em mudança em progresso na variedade do interior paulista, posto que as faixas etárias mais jovens apresentam índices menores de aplicação do processo. No entanto, essa constatação deve ser relativizada devido (i) à proximidade dos PRs ao ponto neutro; e (ii) ao comportamento relativamente diferenciado da faixa etária mais idosa, que apresenta PR bastante próximo àqueles presentes nas faixas etárias de 16 a 25 anos e de 26 a 35 anos.

Concernente à vogal pretônica /o/, a faixa etária intermediária (de 26 a 35 anos) apresenta a maior taxa de aplicação do alçamento, com PR 0.623, seguida pelas faixas etárias mais jovens, de 7 a 15 anos e de 16 a 25 anos, com PRs 0.542 e 0.532, respectivamente. Por sua vez, as faixas etárias mais avançadas, de 36 a 55 anos e acima de 55 anos, desfavorecem o alçamento, com PRs, respectivamente, de 0.456 e 0.385 . Novamente, os resultados quantitativos parecem indicar mudança em progresso, porém, para /o/, em prol da variante alçada. Novamente, deve-se relativizar esse resultado pelos PRs bastante próximos ao ponto neutro, como ilustra o gráfico a seguir.

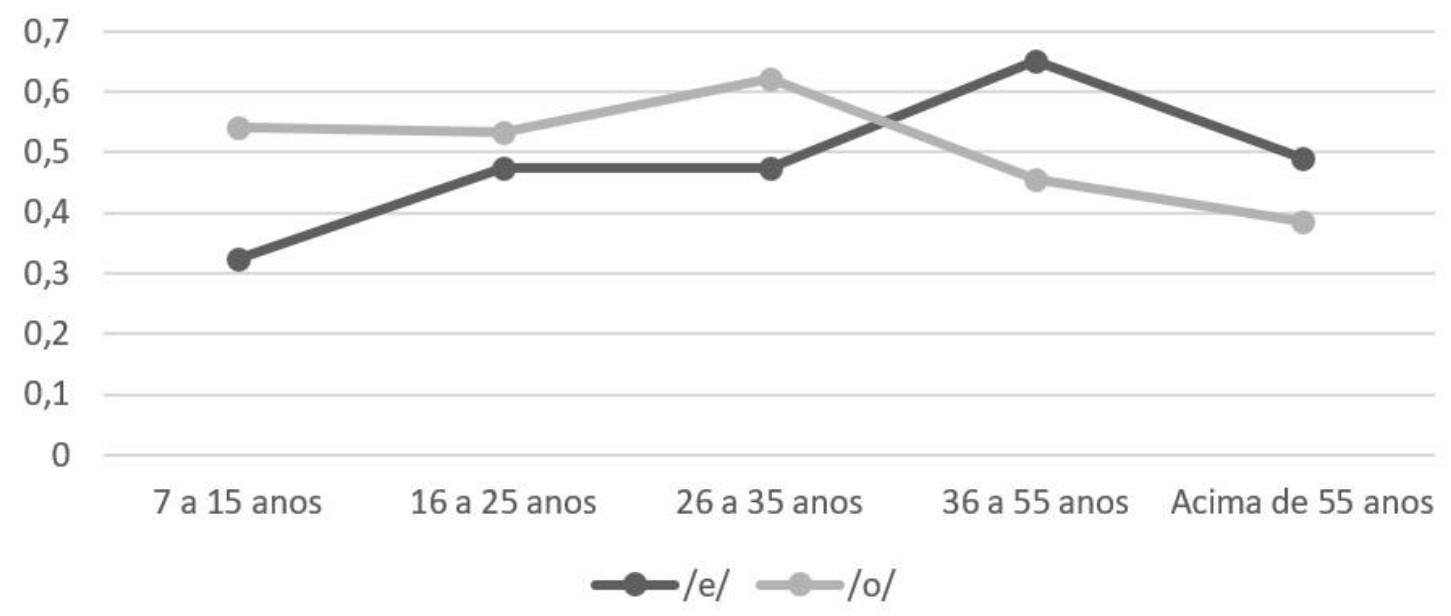

Fonte: Elaborado pelas autoras.

Gráfico 2 - Probabilidades de aplicação do alçamento sem motivação aparente de /e/ e de /o/ em relação às faixas etárias

A investigação minuciosa do status da mudança do alçamento sem motivação aparente das vogais médias pretônicas mediais na variedade do noroeste paulista é deixada para futuras pesquisas, que, por ventura, possam analisar o fenômeno por meio de estudos não só em tempo aparente, como também em tempo real. 
No que diz respeito às variáveis extralinguísticas, portanto, os resultados quantitativos desta pesquisa destacam sua atuação em prol do alçamento sem motivação aparente de /o/, favorecido pelo sexo/gênero masculino. Como mencionado, esse resultado parece indicar, a princípio, estigma social em relação à variante alçada.

Após a análise e a discussão dos dados obtidos nesta investigação, são expostas as considerações finais.

\section{Considerações FinaIs}

O presente trabalho discorreu sobre o alçamento sem motivação aparente das vogais médias pretônicas em contexto medial na variedade falada no noroeste paulista, região onde está situado o município de São José do Rio Preto. Esta pesquisa preenche a lacuna deixada por trabalhos anteriores sobre o alçamento de vogais médias pretônicas nessa variedade (SILVEIRA, 2008; CARMO, 2009, 2013, 2014, 2018, 2019; CARMO; TENANI, 2013) por tratar especificamente do alçamento sem motivação aparente, isto é, que não pode ser explicado por harmonização vocálica.

Este estudo mostra que o alçamento sem motivação aparente no noroeste paulista apresenta baixa produtividade, com taxas de aplicação de 5\% para /e/ e 10,3\% para /o/, resultado semelhante aos obtidos em variedade gaúcha do PB (KLUNCK, 2007; BISOL, 2009; MONARETTO, 2013; SILVA; BIASIBETTI, 2017; BRESCANCINI et al., 2017).

De modo geral, observa-se baixa atuação das variáveis sociais, com exceção do sexo/gênero para o alçamento da vogal pretônica /o/, que demonstra que o sexo/gênero masculino favorece a aplicação do processo. Esse resultado fornece indícios de estigma ao alçamento sem motivação aparente da pretônica posterior na variedade analisada.

Em relação aos contextos linguísticos, constata-se a atuação da atonicidade permanente e da presença de consoante coronal precedente em prol do alçamento de /e/. Já o alçamento de /o/ é favorecido pela estrutura silábica sem preenchimento de coda e pela presença de consoante labial em posição precedente e/ou seguinte. Para ambas as pretônicas, a presença de uma vogal média-alta na sílaba subsequente é apontada como favorecedora do alçamento sem motivação aparente. Sobressaem-se, também, dois contextos destacados por Brescancini et al. (2017): (i) para a pretônica /e/, consoante oclusiva alveolar vozeada precedente e consoante sibilante desvozeada ou vozeada seguinte, como em $d[i]$ smaiei; e (ii) para a pretônica /o/, consoante velar desvozeada precedente, seja em sílaba aberta seguida por consoante nasal ou em sílaba fechada por $/ \mathrm{N} /$, como $c[u] . m$ e.ça e $c[u] m$.pa.dre, respectivamente.

Apesar desses resultados, a verificação dos vocábulos alçados evidencia que o processo é expandido em palavras aparentadas (BISOL, 2009), estando presente em paradigmas de determinados itens lexicais, o que corrobora a hipótese difusionista para a explicação do processo. 
Por fim, espera-se que este trabalho contribua não apenas para o mapeamento das vogais médias pretônicas na variedade do noroeste paulista, como também, de modo mais abrangente, no $\mathrm{PB}$, dado o vínculo da presente pesquisa ao projeto nacional PROBRAVO.

\section{REFERÊNCIAS}

BISOL, L. Harmonia vocálica: uma regra variável. 1981. Tese (Doutorado em Linguística) - Universidade Federal do Rio de Janeiro, Rio de Janeiro, 1981.

BISOL, L. O alçamento da pretônica sem motivação aparente. In: BISOL, L.; COLLISCHONN, G. (Org.). Português do Sul do Brasil: variação fonológica. Porto Alegre: EDIPUCRS, 2009. p. 73-92.

BOERSMA, P.; WEENINK, D. Praat: Doing Phonetics by Computer [Computer program]. Version 6.1. Disponível em: www.praat.org. Acesso em: 12 ago. 2019.

BORTONI, S. M.; GOMES, C. A.; MALVAR, E. A variação das vogais médias pretônicas no português de Brasília: um fenômeno neogramático ou de difusão lexical? Revista de Estudos da Linguagem, Belo Horizonte, v. 1, n. 1, p. 9-30, 1992.

BRESCANCINI, C. R. et al. Alçamento da vogal pré-tônica em Porto Alegre-RS: léxico e variação. ReVEL, ed. esp., n. 14, 2017.

BYBEE, J. Phonology and language use. New York: Cambridge University, 2001.

BYBEE, J. Word frequency and context use in the lexical diffusion of phonetically conditioned sound change. Language, Variation and Change, v. 14, n. 3, p. 261-290, 2002.

BYBEE, J. Language, usage and cognition. New York: Cambridge University, 2010.

CÂMARA JÚNIOR, J. M. Estrutura da língua portuguesa. 40. ed. Petrópolis: Vozes, 2007 [1970].

CARMO, M. C. As vogais médias pretônicas dos verbos na fala culta do interior paulista. 2009. Dissertação (Mestrado em Estudos Linguísticos) - Universidade Estadual Paulista, São José do Rio Preto, 2009.

CARMO, M. C. As vogais médias pretônicas na variedade do interior paulista. 2013. Tese (Doutorado em Estudos Linguísticos) - Universidade Estadual Paulista, São José do Rio Preto, 2013. 
CARMO, M. C. As vogais médias pretônicas no noroeste paulista: comparação com outras variedades do Português Brasileiro. Estudos Linguísticos, v. 43, n. 1, p. 33-47, jan./abr. 2014.

CARMO, M. C. Variação linguística das vogais médias pretônicas em contexto medial no noroeste paulista. Uniletras, Ponta Grossa, v. 40, n. 2, p. 222-240, jul./dez. 2018.

CARMO, M. C. Alçamento vocálico das vogais médias pretônicas iniciais na variedade do noroeste paulista. Estudos Linguísticos, v. 48, n. 2, p. 800-821, jul. 2019.

CARMO, M. C.; TENANI, L. E. As vogais médias pretônicas na variedade do noroeste paulista. Alfa, São Paulo, v. 57, n. 2, p. 607-637, 2013.

CASSIQUE, O. et al. Análise do processo de alteamento das vogais médias pretônicas no Português falado em Breves (PA). In: HORA, D. da. (Org.). Vogais: no ponto mais oriental das Américas. João Pessoa: Ideia, 2009. p. 111-132.

CHAMBERS, J. K. Sociolinguistic Theory: Linguistic variation and its social significance. West Sussex: Wiley-Blackwell, 2009 [1995].

CHENG, C. C.; WANG, W. S-Y. Tone change in Chao-zhou Chinese: A study in lexical diffusion. In: WANG, W. S-Y. (Ed.). The lexicon in phonological change. The Hague: Mouton, 1977. p. 86-100.

COLLISCHONN, G. A sílaba em português. In: BISOL, L. (Org.) Introdução a estudos de fonologia do Português Brasileiro. 2. ed. Porto Alegre: EDIPUCRS, 1999. p. 91-119.

COLLISCHONN, G.; SCHWINDT, L. C. Harmonia vocálica no sistema verbal do português do Sul do Brasil. Estudos de Fonologia e de Morfologia, Porto Alegre, v. 18, n. 36, p. 73-82, 2004.

GONÇALVES, S. C. L. Banco de dados Iboruna: amostras eletrônicas do português falado no interior paulista. 2007. Disponível em: iboruna.ibilce.unesp.br. Acesso em: 12 ago. 2019.

GUY, G.; ZILLES, A. Sociolingüistica quantitativa: instrumental de análise. São Paulo: Parábola, 2007.

HUTCHESON, J. W. Remarks on the nature of complete consonantal assimilations. In: CORUM, C. W.; SMITH-STARK, T. C.; WEISER, A. (Ed.). Papers from the Ninth Regional Meeting of the Chicago Linguistic Society. Chicago: University of Chicago, 1973. p. 215-222.

ILARI, R. Linguística Românica. 2. ed. São Paulo: Contexto, 2018. 
JOHNSON, K. Speech perception without speaker normalization: An exemplar model. In: JOHNSON, K.; MULLENNIX, J. Talker variability in speech processing. San Diego: Academic, 1997. p. 145-165.

KLUNCK, P. Alçamento das vogais médias pretônicas sem motivaşão aparente. 2007. Dissertação (Mestrado em Letras) - Pontifícia Universidade Católica do Rio Grande do Sul, Porto Alegre, 2007.

LABOV, W. Building on empirical foundations. In: LEHMANN W. P.; MALKIEL, Y. (Ed.). Perspectives on Historical Linguistics. Amsterdam; Philadelphia: John Benjamins, 1982. p. 17-92.

LABOV, W. Padrões sociolinguísticos. Tradução de Marcos Bagno, Maria Marta Pereira Scherre e Caroline Rodrigues Cardoso. São Paulo: Parábola, 2008 [1972].

MONARETTO, V. N. O. O alçamento das vogais médias pretônicas /e/ e /o/ sem motivação aparente: um estudo em tempo real. Fragmentum, n. 39, p. 18-28, out./dez. 2013.

OLIVEIRA, M. A. Aspectos da difusão lexical. Revista de Estudos da Linguagem, Belo Horizonte, a. 1, v. 1, p. 31-41, jul./dez. 1992.

PAIVA, M. C.; DUARTE, M. E. L. Mudança linguística: observações no tempo real. In: MOLLICA, M. C.; BRAGA, M. L. (Org.). Introdução à Sociolinguística: o tratamento da variação. 4. ed. São Paulo: Contexto, 2013. p. 179-190.

PIERREHUMBERT, J. Exemplar dynamics: word frequency, lenition and contrast. In: BYBEE, J.; HOPPER, P. Frequency and the emergence of Linguistic Structure. Amsterdam: Benjamins, 2001. p. 137-157.

PIERREHUMBERT, J. Word specific Phonetics. In: GUSSENHOVEN, C.; WARNER, N. (Ed.). Laboratory Phonology 7. The Hague: Mouton de Gruyter, 2002. p. 101-139.

PIERREHUMBERT, J. Phonetic diversity, statistical, learning, and acquisition of Phonology. Language and Speech, n. 46, p. 115-154, 2003.

SELKIRK, E. The syllable. In: HULST, H.; SMITH, N. (Ed.). The structure of phonological representations (Part II). Dordrecht: Foris, 1982. p. 337-383.

SILVA, T. C. Dicionário de Fonética e Fonologia. São Paulo: Contexto, 2011.

SILVA, S. M.; BIASIBETTI, A. P. C. S. O papel do léxico no alçamento sem motivação aparente das vogais médias pretônicas no português brasileiro. Revista de Estudos da Linguagem, Belo Horizonte, v. 25, n. 1, p. 151-178, 2017. 
SILVA-CORVALÁN, C. Sociolingüistica: teoría y análisis. Madrid: Alhambra, 1989.

SILVEIRA, A. A. M. As vogais pretônicas na fala culta do noroeste paulista. 2008.

Dissertação (Mestrado em Estudos Linguísticos) - Universidade Estadual Paulista, São José do Rio Preto, 2008.

WANG, W.S-Y. Competing changes as a cause of residues. Language 45, p. 9-25, mar. 1969.

WEINREICH, U.; LABOV, W.; HERZOG, M. I. Fundamentos empiricos para uma teoria da mudança linguística. Tradução de Marcos Bagno. São Paulo: Parábola, 2006 [1968]. 